\title{
Thermal Stability of Conductive and Transparent V-Doped ZnO Thin Films
}

\author{
Hiroshi Chiba*, Tatsuya Mori, Shuhei Okuda, and Katsuyoshi Washio \\ Graduate School of Engineering, Tohoku University, \\ 6-6-05 Aza-Aoba, Aramaki, Aoba-ku, Sendai 980-8579, Miyagi, Japan \\ *Correspondence: Te1: +81-22-795-7122, Fax: +81-22-263-9396, \\ E-mail: chiba-h@ecei.tohoku.ac.jp
}

\begin{abstract}
The thermal stability of electrical, optical and structural properties of vanadium-doped zinc oxide (VZO) thin films has been investigated after heat treatments up to $550{ }^{\circ} \mathrm{C}$ in $\mathrm{N}_{2}$ and $\mathrm{O}_{2}$ atmospheres. $\mathrm{ZnO}$ and $\mathrm{VZO}$ films were prepared by RF magnetron sputtering on quartz substrates at $200{ }^{\circ} \mathrm{C}$. It was found that the resistivity of VZO films remains low at about $5 \times 10^{-4} \Omega \mathrm{cm}$ when heat treated at temperature up to $450{ }^{\circ} \mathrm{C}$ in both $\mathrm{N}_{2}$ and $\mathrm{O}_{2}$ atmosphere, while resistivity of $\mathrm{ZnO}$ film increased remarkably due to the compensation of oxygen vacancies in $\mathrm{O}_{2}$ heat treatments over $400{ }^{\circ} \mathrm{C}$. Optical transmittance of as-grown VZO film in the visible range $(400 \sim 1100 \mathrm{~nm})$ was $20-30 \%$ and improved up to about $80 \%$ when heat treated at temperature up to $500{ }^{\circ} \mathrm{C}$ in $\mathrm{N}_{2}$ and $\mathrm{O}_{2}$ atmospheres. Decreased c-axis lattice constant in VZO film was larger in $\mathrm{N}_{2}$ heat treatments than in $\mathrm{O}_{2}$ heat treatments. Based on these experimental results, we made the hypothesis that V-O bonds similar to vanadium trioxide in as-grown VZO film changed to those similar to
\end{abstract}


vanadium pentoxide after heat treatments over $500{ }^{\circ} \mathrm{C}$.

Keywords: RF magnetron sputtering

$\mathrm{ZnO}$

Vanadium

Heat treatment

Thermal stability

Resistivity 


\section{Introduction}

Transparent conductive electrodes play a major role in the fields of information and energy technologies [1]. ZnO thin films have been studied extensively as component of flat-panel displays and solar cells. Doped ZnO thin films with low-resistivity and transparent properties comparable to indium tin oxide (ITO) have particularly been investigated [2,3]. However, resistivity of doped-ZnO films have been shown to become unstable at relatively low temperature range of $300-400{ }^{\circ} \mathrm{C}[3-5]$.

Transition-metal doped $\mathrm{ZnO}$ films have a variety of attractive properties, such as ferromagnetic behavior and piezoelectricity [6-9]. Among them, low-resistivity vanadium-doped $\mathrm{ZnO}$ (VZO) films have a potential to extend further functionality $[10,11]$. However, the number of studies concerning thermal stability of VZO is limited $[12,13]$. Therefore, in this paper, thermal stability of VZO thin films in terms of electrical, optical and structural properties has been investigated for heat treatments up to $550{ }^{\circ} \mathrm{C}$ in $\mathrm{N}_{2}$ and $\mathrm{O}_{2}$ atmospheres.

\section{Experiment}

$\mathrm{ZnO}$ and $\mathrm{VZO}$ thin films were deposited on quartz substrates by RF magnetron sputtering. The gas used during the deposition was Ar (1.0 Pa). RF power and the substrate temperatures were $150 \mathrm{~W}$ and $200{ }^{\circ} \mathrm{C}$, respectively. The deposition rate was $16 \sim 18 \mathrm{~nm} / \mathrm{min}$ and the thickness of $\mathrm{ZnO}$ and $\mathrm{VZO}$ was about $500 \mathrm{~nm}$. V was doped by co-sputtering ceramic $\mathrm{ZnO}$ with $\mathrm{V}$ chips. V concentration of about 1.9 at.\% was measured by X-ray fluorescence (XRF, Rigaku RIX2100 using Rh radiation). The 
$\mathrm{ZnO}$ and $\mathrm{VZO}$ thin films were heat-treated up to $550^{\circ} \mathrm{C}$ for 5 minutes in $\mathrm{N}_{2}$ or $\mathrm{O}_{2}$ atmospheres (1000 Pa) to investigate their thermal stability. Heanting and cooling rates were $60^{\circ} \mathrm{C} / \mathrm{min}$ and $100^{\circ} \mathrm{C} / \mathrm{min}$, respectively, to avoid excessive stress in the films. Thermal stability was evaluated by the change in resistivity, optical transmittance, crystallinity, and surface morphology. Resistivity was measured by the Van-der-Pauw method and optical transmittance was measured using a spectrophotometer in the range of 300 to $1100 \mathrm{~nm}$. The c-axis crystalline orientation was confirmed by out-of-plane X-ray diffraction (XRD, Rigaku SmartLab

using $\mathrm{CuK} \alpha$ radiation) measurements. The surface morphology was observed with atomic force microscopy (Park XE-100, in non-contact $\operatorname{mode})$

\section{Results}

\section{3-1 Resistivity}

Dependence of resistivity on heat treatment temperature $\left(\mathrm{T}_{\mathrm{A}}\right)$ in $\mathrm{N}_{2}$ or $\mathrm{O}_{2}$ atmospheres for $\mathrm{ZnO}$ and $\mathrm{VZO}$ films are shown in Fig. 1. Resistivity of as-grown $\mathrm{ZnO}$ and $\mathrm{VZO}$ films were $0.1 \Omega \mathrm{cm}$ and $0.5 \mathrm{~m} \Omega \mathrm{cm}$, respectively. Okuda et al. reported that low resistivity of about $5 \times 10^{-4}$ $\Omega$ cm observed in VZO films was due to $\mathrm{V}$ dominant charge number of +3 [11]. That is, V atoms in VZO films have V-O bonds similar to vanadium trioxide $\left(\mathrm{V}_{2} \mathrm{O}_{3}\right)$ resistivity of which is about $10^{-4} \Omega \mathrm{cm}$.

In the case of $\mathrm{N}_{2}$ heat treatment, the resistivity of $\mathrm{ZnO}$ film increased slightly over $\mathrm{T}_{\mathrm{A}}$ of $450^{\circ} \mathrm{C}$ and, in general, this has beenthought to be due to the desorption of interstitial $\mathrm{Zn}$ atoms $\left(\mathrm{Zn}_{\mathrm{i}}\right)[14]$. On the other hand, the resistivity of $\mathrm{VZO}$ films remained low up to $\mathrm{T}_{\mathrm{A}}$ of $450{ }^{\circ} \mathrm{C}$ and rose 
sharply at $\mathrm{T}_{\mathrm{A}}=500^{\circ} \mathrm{C}$. Here, it is notable that resistivity of $\mathrm{ZnO}$ and $\mathrm{VZO}$ films after $\mathrm{N}_{2}$ heat treatment at 500 and $550^{\circ} \mathrm{C}$ was nearly equal. This means that the number of free carriers bringing conductivity was almost the same and $\mathrm{V}^{3+}$ ions should disappear in VZO film following $\mathrm{N}_{2}$ heat treatment at $500{ }^{\circ} \mathrm{C}$.

In the case of $\mathrm{O}_{2}$ heat treatment, a remarkable increase (about $10^{4}$ times) of resistivity was observed in $\mathrm{ZnO}$ films annealed between $\mathrm{T}_{\mathrm{A}}$ of 400 and $450{ }^{\circ} \mathrm{C}$. Comparing with $\mathrm{N}_{2}$ heat treatment, this indicates that compensation of oxygen vacancies $\left(\mathrm{V}_{\mathrm{O}}\right)$ occurred by $\mathrm{O}_{2}$ heat treatment [15]. Resistivity of $\mathrm{ZnO}$ film became saturated at $\mathrm{T}_{\mathrm{A}}$ of over $450^{\circ} \mathrm{C}$ due to the full compensation of $V_{O}$. On the other hand, resistivity of VZO film kept unchanged up to $\mathrm{T}_{\mathrm{A}}$ of $450^{\circ} \mathrm{C}$ in contrast to $\mathrm{ZnO}$ film and increased at $500^{\circ} \mathrm{C}$. Here, we notice again that the resistivity of VZO film after $\mathrm{O}_{2}$ heat treatment at $500{ }^{\circ} \mathrm{C}$ was nearly equal to that of $\mathrm{ZnO}$ and VZO films after $\mathrm{N}_{2}$ heat treatment at $500{ }^{\circ} \mathrm{C}$. This means that the increase in resistivity of VZO films after $\mathrm{N}_{2}$ and $\mathrm{O}_{2}$ heat treatments at $500{ }^{\circ} \mathrm{C}$ occurred by the same phenomenon, i.e. the disappearance of $\mathrm{V}^{3+}$ ions. Here, it should be noted that there was no decrease in V concentration of VZO film measured by XRF after any heat treatments. Furthermore, as a result of thermal stability up to $\mathrm{T}_{\mathrm{A}}$ of $450{ }^{\circ} \mathrm{C}$, it should be considered that doping of $\mathrm{V}$ disturbed the compensation of oxygen vacancies.

\section{3-2 Transmittance}

Optical transmission spectra in the wavelength range from 300 to $1100 \mathrm{~nm}$ for as-grown and heat-treated $\mathrm{ZnO}$ and $\mathrm{VZO}$ films of $\mathrm{T}_{\mathrm{A}}$ up to $500{ }^{\circ} \mathrm{C}$ are shown in Fig. 2. Dependence of optical transmittance at a 
wavelength of $500 \mathrm{~nm}$ on $\mathrm{T}_{\mathrm{A}}$ are shown in Fig. 3. Optical transmittance of the quartz substrate was about $90 \%$. Optical transmittance for ZnO films was about $80 \%$ in the visible range $(400 \mathrm{~nm} \sim 1100 \mathrm{~nm})$ and was stable when heat treated in both $\mathrm{N}_{2}$ and $\mathrm{O}_{2}$ atmospheres. This means that the desorption of $\mathrm{Zn}_{i}$ and the compensation of $\mathrm{V}_{\mathrm{O}}$ did not affect the optical transmittance. On the other hand, for as-grown VZO, transmittance was $20-30 \%$. Here, as described in section $3-1$, V ions with the charge number of +3 were incorporated into VZO films. So, it is considered that this decrease of transmittance of VZO film is due to the formation of $\mathrm{V}-\mathrm{O}$ bonds similar to $\mathrm{V}_{2} \mathrm{O}_{3}$. Note that $\mathrm{V}_{2} \mathrm{O}_{3}$ is opaque. Transmittance of VZO film increased with $\mathrm{T}_{\mathrm{A}}$ and raised to about $80 \%$ at $\mathrm{T}_{\mathrm{A}}$ of $500{ }^{\circ} \mathrm{C}$ in both $\mathrm{N}_{2}$ and $\mathrm{O}_{2}$ atmospheres. This $\mathrm{T}_{\mathrm{A}}$ is equal to the temperature at which resistivity of $\mathrm{VZO}$ films after $\mathrm{N}_{2}$ and $\mathrm{O}_{2}$ heat treatments increased. Furthermore, at $\mathrm{T}_{\mathrm{A}}$ over $500^{\circ} \mathrm{C}$, transmittance of both $\mathrm{ZnO}$ and VZO films was almost equal. This means that the disappearance of $\mathrm{V}^{3+}$ ions attributed to improve transparency in $\mathrm{VZO}$ film.

\section{3-3 Crystallinity}

The XRD patterns of as-grown and heat-treated $\mathrm{ZnO}$ and $\mathrm{VZO}$ films at $\mathrm{T}_{\mathrm{A}}$ up to $500{ }^{\circ} \mathrm{C}$ are shown in Fig. 4. The crystallinity is characterized by intensive diffraction peak from (0002) plane. Peaks from (10-11), (10-12), (10-13) and (11-22) planes other than the c-axis orientation were identified in $\mathrm{ZnO}$ films. Similar diffraction patterns have been observed after heat treatments in both $\mathrm{N}_{2}$ and $\mathrm{O}_{2}$ atmospheres and there was no significant change in crystallinity. Peaks from (10-11), (10-12) 
and (10-13) planes were also observed in VZO films and there was also no specific change after heat treatments in both $\mathrm{N}_{2}$ and $\mathrm{O}_{2}$ atmospheres. That is, it could be considered that the crystallinity was not changed much through heat treatments. Comparing with $\mathrm{ZnO}$, the diffraction peak from (10-11) plane was weak and there was no peak from (11-22) plane in VZO film, however, the heat treatments do not seem to affect the cystallinity of the VZO films, either.

The dependence of c-axis lattice constant on $\mathrm{T}_{\mathrm{A}}$, estimated from the diffraction angle of the (0002) plane peak, is shown in Fig. 5. Both $\mathrm{ZnO}$ and VZO films shrank along [0001] direction when heat treated in $\mathrm{N}_{2}$ or $\mathrm{O}_{2}$ atmospheres. In the case of $\mathrm{N}_{2}$ heat treatment, the c-axis lattice constant of $\mathrm{ZnO}$ films decreased linearly with increasing $\mathrm{T}_{\mathrm{A}}$ over $350{ }^{\circ} \mathrm{C}$ and that of VZO films decreased with increasing $\mathrm{T}_{\mathrm{A}}$ similar to $\mathrm{ZnO}$ films. However, the c-axis lattice constant of VZO films varied widely and became almost equal to that of $\mathrm{ZnO}$ films at $\mathrm{T}_{\mathrm{A}}$ of $550{ }^{\circ} \mathrm{C}$. This decrease of c-axis lattice constant is also attributed to the desorption of $\mathrm{Zn}_{\mathrm{i}}$. However, the larger shrinkage for VZO films than ZnO films cannot be explained only by the desorption of $\mathrm{Zn}_{\mathrm{i}}$. This is because the concentration of $\mathrm{Zn}_{\mathrm{i}}$ in $\mathrm{ZnO}$ films is thought to be given by the substrate temperature [16], so the $\mathrm{Zn}_{\mathrm{i}}$ concentration of VZO films was considered to be equal to that of $\mathrm{ZnO}$ films. The ionic radius of $\mathrm{V}^{5+}$ with a coordination number of 4 is about half that of $\mathrm{V}^{3+}$ with a coordination number of 6 and tetrahedrally coordinated $\mathrm{V}^{5+}$ is more stable in the hexagonal-system $\mathrm{ZnO}$ crystal structure. Here, we introduce the hypothesis that V-O bonds similar to $\mathrm{V}_{2} \mathrm{O}_{3}$ for as-grown VZO films changed to bonds similar to vanadium pentoxide $\left(\mathrm{V}_{2} \mathrm{O}_{5}\right)$ after heat 
treatments. The disappearance of $\mathrm{V}^{3+}$ ions, that was derived from the results of changes in resistivity and optical transmittance by $\mathrm{N}_{2}$ and $\mathrm{O}_{2}$ heat treatments, is consistent with this hypothesis.

In the case of $\mathrm{O}_{2}$ heat treatment, the c-axis lattice constant for both $\mathrm{ZnO}$ and $\mathrm{VZO}$ films also decreased with increasing $\mathrm{T}_{\mathrm{A}}$ similar to the case of $\mathrm{N}_{2}$ heat treatment. However, the shrinkage of the c-axis lattice constant in $\mathrm{O}_{2}$ heat treatment was smaller than that in $\mathrm{N}_{2}$ heat treatment. This means that the compensation of $V_{O}$ caused by the supply of $O$ atoms with the large ionic radius alleviated the shrinkage in the c-axis direction. This also follows that the shrinkage of the c-axis lattice constants of ZnO and VZO films changed by nearly the same dependence on $\mathrm{T}_{\mathrm{A}}$.

\section{3-4 Surface morphology}

The surface morphologies of $\mathrm{ZnO}$ and VZO films are shown in Fig.6. The root-mean-square surface roughness of as-grown $\mathrm{ZnO}$ and VZO films was estimated at $10.5 \mathrm{~nm}$ and $3.3 \mathrm{~nm}$, respectively. The grain size became small and the surface became smooth in VZO films caused by V doping. However, for both $\mathrm{ZnO}$ and VZO films, it was observed that the surface morphology and columnar structure was not changed much through heat treatments in both $\mathrm{N}_{2}$ and $\mathrm{O}_{2}$ atmospheres up to $500^{\circ} \mathrm{C}$. This corresponds with the evaluation result of crystallinity.

\section{Discussion}

We consider the most characteristic difference in thermal stability between $\mathrm{ZnO}$ and VZO films comes mainly from the change of valence 
state of $\mathrm{V}$ ions by the heat treatment. That is, $\mathrm{V}-\mathrm{O}$ bonds similar to $\mathrm{V}_{2} \mathrm{O}_{3}$ changed to those similar to $\mathrm{V}_{2} \mathrm{O}_{5}$ at $\mathrm{T}_{\mathrm{A}}$ over $500{ }^{\circ} \mathrm{C}$. The most remarkable result was that low-resistive VZO film was kept stable up to $\mathrm{T}_{\mathrm{A}}$ of $450^{\circ} \mathrm{C}$ while the resistivity of $\mathrm{ZnO}$ increased drastically at $\mathrm{T}_{\mathrm{A}}$ of $400{ }^{\circ} \mathrm{C}$ in $\mathrm{O}_{2}$ heat treatment. This is considered to be a contribution of the obstruction of the $\mathrm{V}_{\mathrm{O}}$ compensation by $\mathrm{V}$ doping. The change of $\mathrm{V}-\mathrm{O}$ bonds similar to $\mathrm{V}_{2} \mathrm{O}_{3}$ to bonds similar to $\mathrm{V}_{2} \mathrm{O}_{5}$ as a result of heat treatment is the hypothesis at present. However, the changes of resistivity, transmittance, and the c-axis lattice constant by $\mathrm{N}_{2}$ and $\mathrm{O}_{2}$ heat treatments can be explained consistently. This hypothesis is indirectly supported by the fact that $\mathrm{V}_{2} \mathrm{O}_{5}$ has relatively high-resistivity of about $10^{2}$ to $10^{3} \Omega \mathrm{cm}$ $\left(\mathrm{V}_{2} \mathrm{O}_{3}: 10^{-4} \Omega \mathrm{cm}\right)$ and its color is light orange (while $\mathrm{V}_{2} \mathrm{O}_{3}$ is: black). Of course, we consider that further physical analyses are necessary to verify this hypothesis and we would like to continue the study in this respect.

\section{Conclusion}

The thermal stability of electrical, optical and structural properties of VZO thin films was investigated after heat treatments up to $550^{\circ} \mathrm{C}$ in $\mathrm{N}_{2}$ and $\mathrm{O}_{2}$ atmospheres. VZO films kept low resistivity after heat treatments up to $450^{\circ} \mathrm{C}$. Optical transmittance of VZO films improved up to about $80 \%$ at $500{ }^{\circ} \mathrm{C}$. Decreased c-axis lattice constant in VZO films was larger in $\mathrm{N}_{2}$ heat treatments than in $\mathrm{O}_{2}$ heat treatments. We made a hypothesis that V-O bonds similar to vanadium trioxide in as-grown VZO film changed to those similar to vanadium pentoxide after heat treatments over $500{ }^{\circ} \mathrm{C}$. This explained the changes of VZO properties after heat treatments consistently. 


\section{Acknowledgments}

This study was partially supported by The Industry-Academia Collaborative R\&D Programs from The Japan Science and Technology

Agency, and by JSPS Core-to-Core Programs, A. Advanced Research Networks.

\section{References}

[1] K. Ellmer, Nature Photon. 6 (2012) 809.

[2] T. Minami, Semicond. Sci. Technol. 20 (2005) S35.

[3] W. J. Lee, C. R. Cho, K. M. Cho, S. Y. Jeong, J. Korean Phys. Soc.47 (2005) S296.

[4] K. Yim, H. W. Kim, C. Lee, Mater. Sci. Technol. 23 (2007) 108.

[5] T. Minami, H. Nanto, S. Shooji, S. Tanaka, Jap. J. Appl. Phys. 23 (1984) 280.

[6] R. Janisch, P. Gopal, N. A. Spaldin, J. Phys. Condens. Matter 17 (2005) 657.

[7] N. A. Spaldin, Phys. Rev. B 69 (2004) 125201.

[8] C. Song, Phys. Rev. B 76 (2007) 045215.

[9] H. Saeki, H. Tabata, T. Kawai, Solid State Commun. 120 (2001) 439.

[10] K. Lovshinov, H. Nichev, O. Angelov, M. S. Vassileva, V. Mikli, D. D. Malinovska, J. Phys. Conf. Ser. 253 (2010) 012030.

[11] S. Okuda, T. Matsuo, H. Chiba. T. Mori, K. Washio, ISCSI-VI, P2-27 (2013).

[12] S. H. Liu, H. S. Hsu, C. R. Lin, C. S. Lue, J. C. A. Huang, Appl, Phys. Lett. 222505 (2007) 90.

[13] N. Tahir, S. T. Hussain M. Usman, S. K. Hasanain, A. Mumtaz, Appl. Surf. Sci. 255 (2009) 8506.

[14] D. G. Thomas, J. Phys. Chem. Solids, 3 (1957) 229.

[15] L. Cui, H. Y Zhang, G. G. Wang, F. Z. Yang, X. P. Kuang, R. Sun, J. C. Han, App1 
Surf. Sci. 258 (2012) 2479.

[16] Y. Igasaki, H. Saito, J. Appl. Phys. 69 (1991) 2190. 


\section{Figure Captions}

Fig. 1. Dependence of resistivity on $\mathrm{T}_{\mathrm{A}}$ in (a) $\mathrm{N}_{2}$ and (b) $\mathrm{O}_{2}$ atmospheres for $\mathrm{ZnO}$ and $\mathrm{VZO}$ films.

Fig. 2. Optical transmission spectra for as-grown and heat-treated $\mathrm{ZnO}$ films at $\mathrm{T}_{\mathrm{A}}$ of $400,450,500{ }^{\circ} \mathrm{C}$ in (a) $\mathrm{N}_{2}$ and (b) $\mathrm{O}_{2}$ atmospheres, and as-grown and heat-treated $\mathrm{VZO}$ films at $\mathrm{T}_{\mathrm{A}}$ of $400,450,500{ }^{\circ} \mathrm{C}$ in (c) $\mathrm{N}_{2}$ and (d) $\mathrm{O}_{2}$ atmospheres.

Fig. 3. Dependence of optical transmittance at wavelength of $500 \mathrm{~nm}$ on $\mathrm{T}_{\mathrm{A}}$ in $\mathrm{N}_{2}$ and $\mathrm{O}_{2}$ atmospheres for $\mathrm{ZnO}$ and $\mathrm{VZO}$ films.

Fig. 4. XRD patterns of as-grown and heat-treated (a) $\mathrm{ZnO}$ and (b) VZO films at $\mathrm{T}_{\mathrm{A}}$ of 400 and $500{ }^{\circ} \mathrm{C}$ in $\mathrm{N}_{2}$ and $\mathrm{O}_{2}$ atmospheres.

Fig. 5. Dependence of c-axis lattice constant for $\mathrm{ZnO}$ and VZO films on $\mathrm{T}_{\mathrm{A}}$ in $\mathrm{N}_{2}$ and $\mathrm{O}_{2}$ atmospheres for $\mathrm{ZnO}$ and $\mathrm{VZO}$ films.

Fig. 6. Surface morpholog Y of ZnO film for (a) as-grown, heat-treated at $\mathrm{T}_{\mathrm{A}}$ of $500^{\circ} \mathrm{C}$ in (b) $\mathrm{N}_{2}$, and (c) $\mathrm{O}_{2}$ atmospheres, and VZO film for (d) as-grown, heat-treated at $\mathrm{T}_{\mathrm{A}} 500^{\circ} \mathrm{C}$ in (e) $\mathrm{N}_{2}$, and (f) $\mathrm{O}_{2}$ atmospheres. 
Fig. 1 H. Chiba et al.
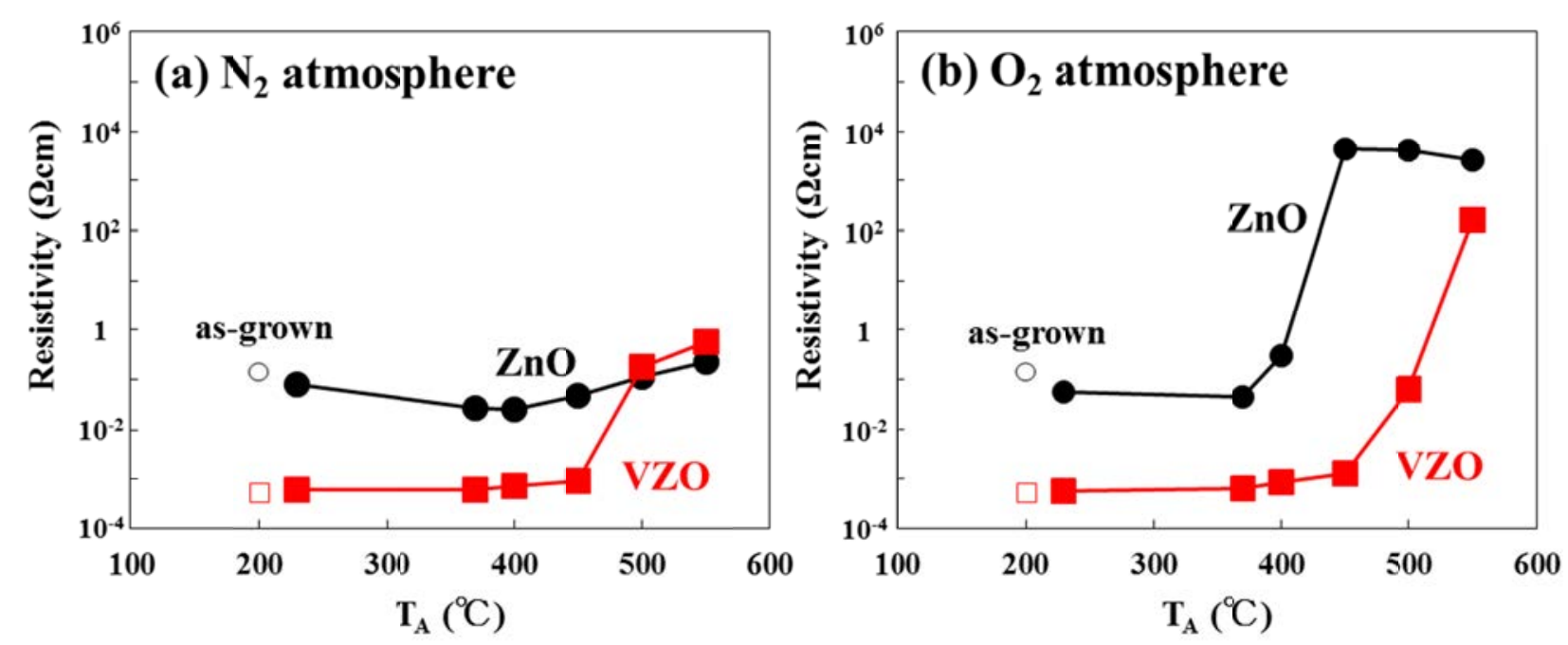
Fig. 2 H. Chiba et al.
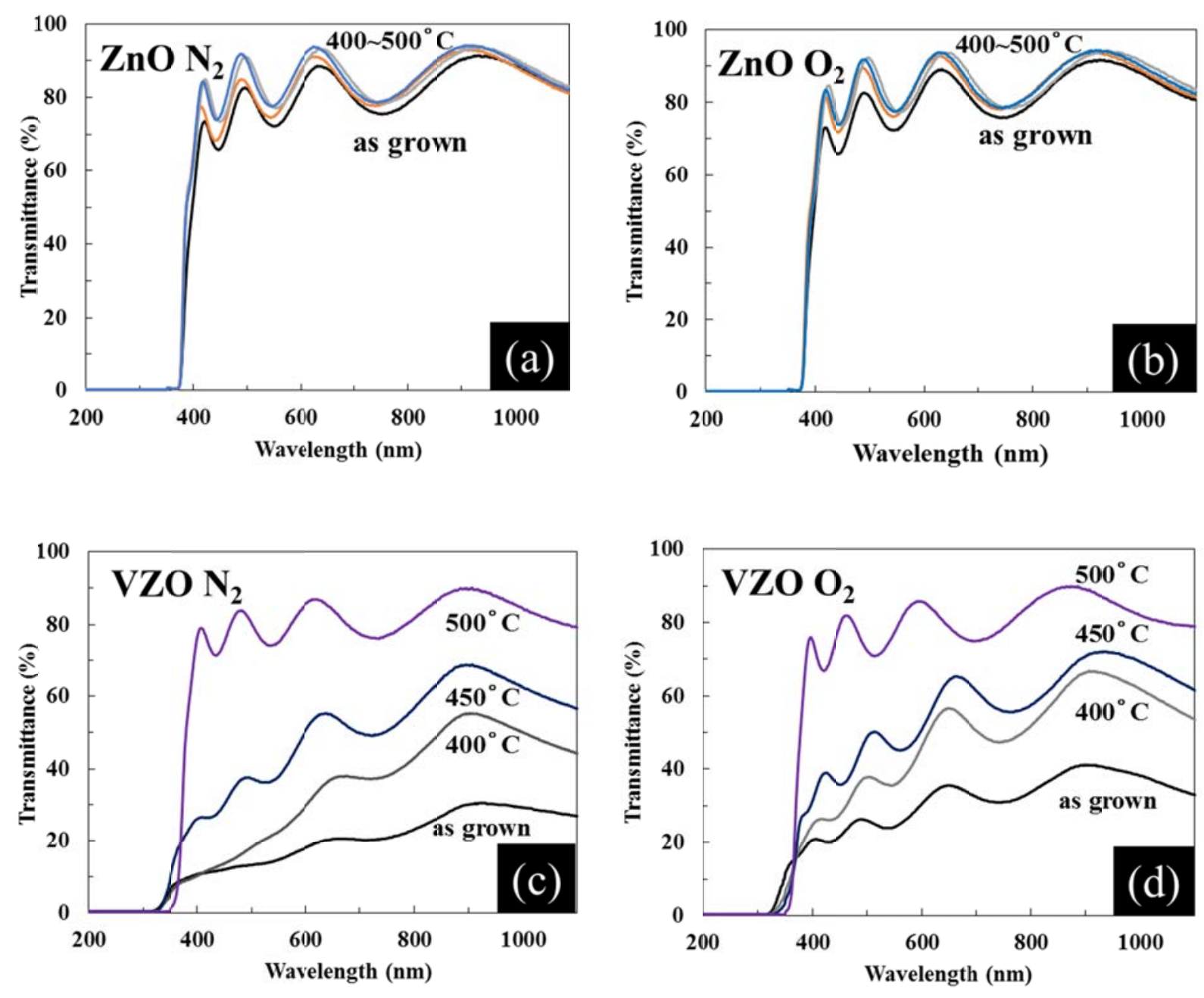
Fig. 3 H. Chiba et al.

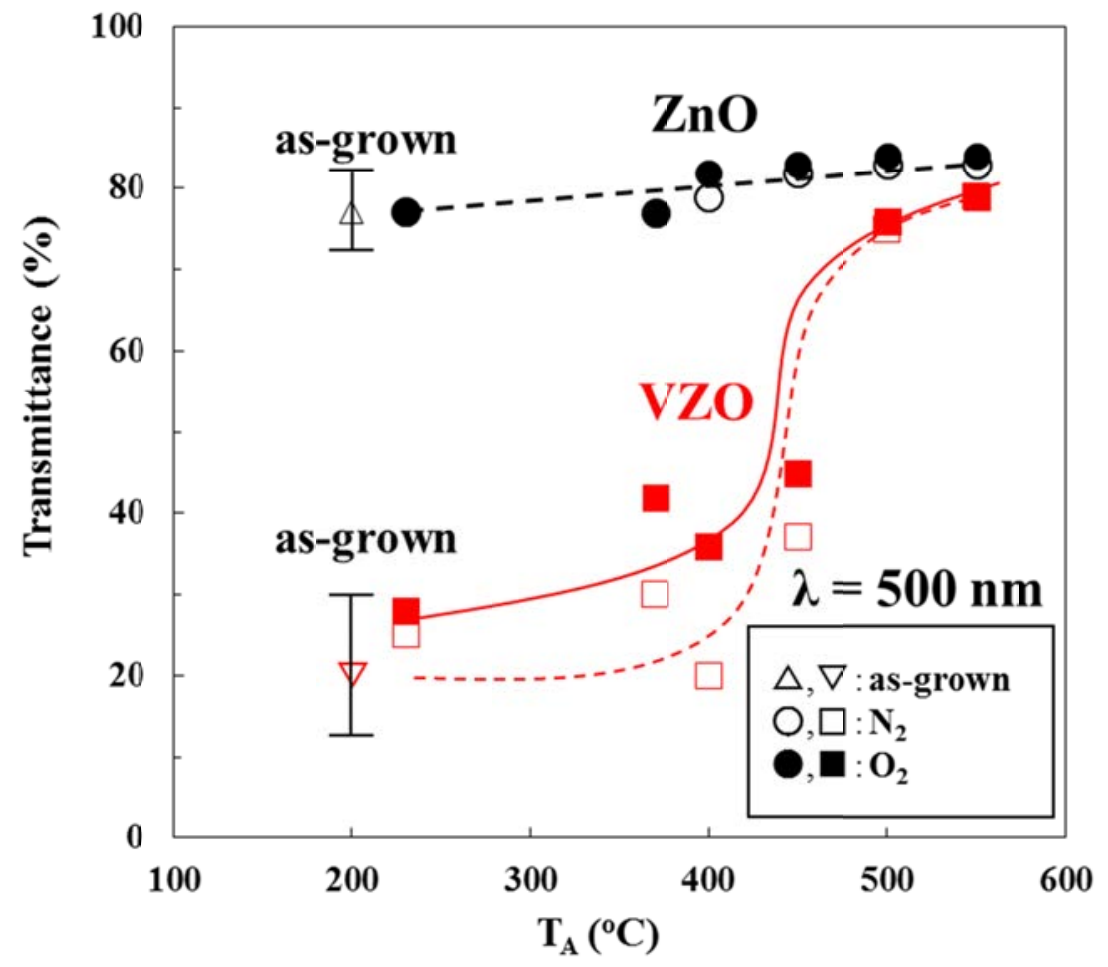


Fig. 4 H. Chiba et al.

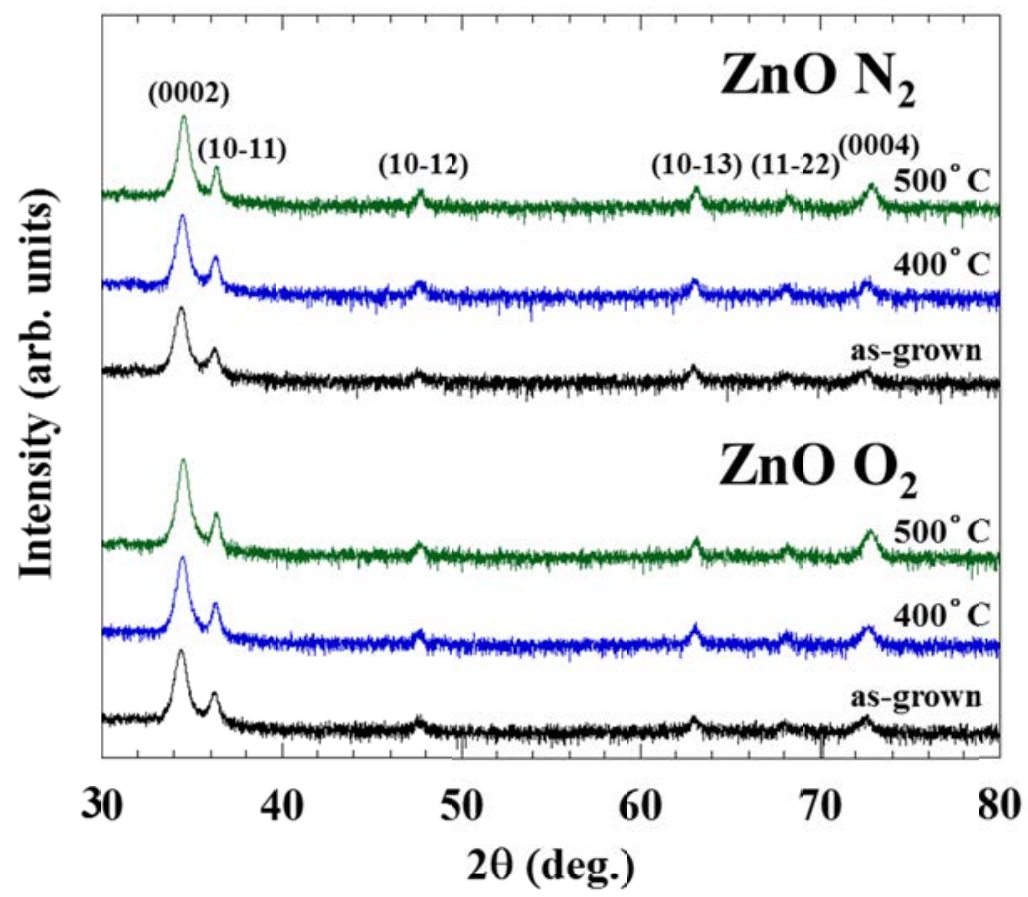

(a)

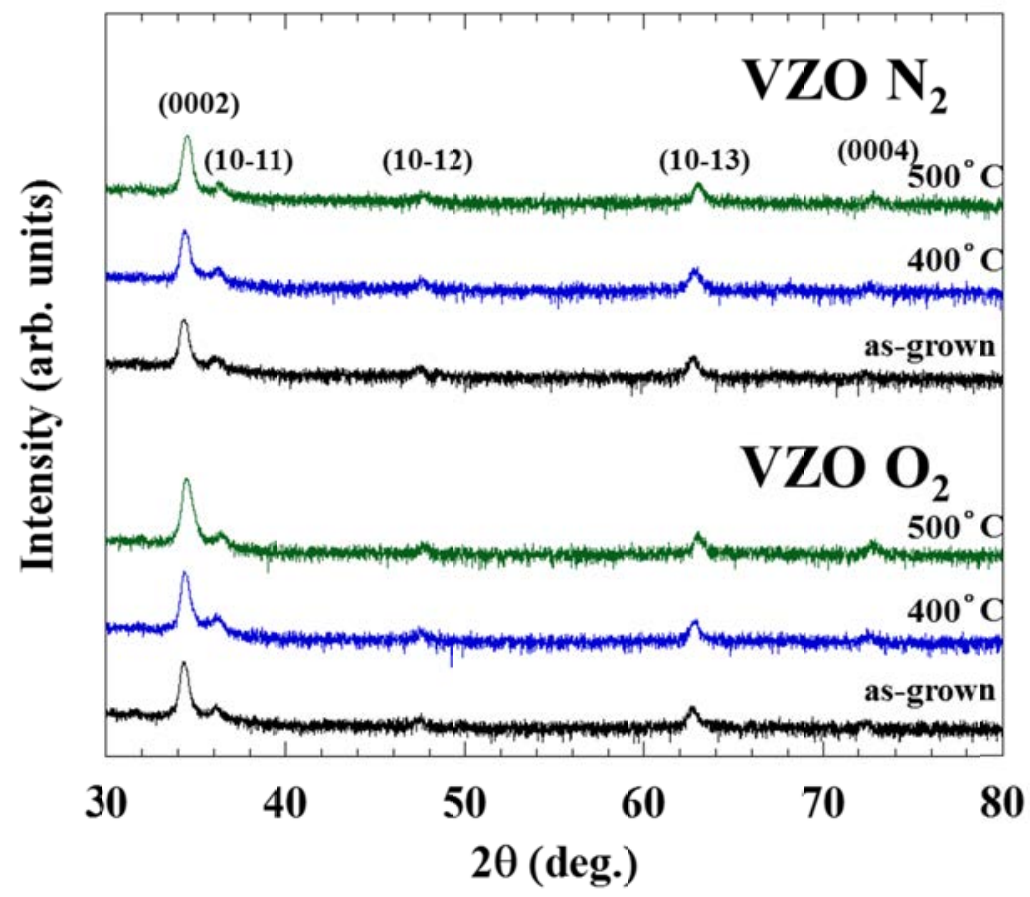

(b) 
Fig. 5 H. Chiba et al.

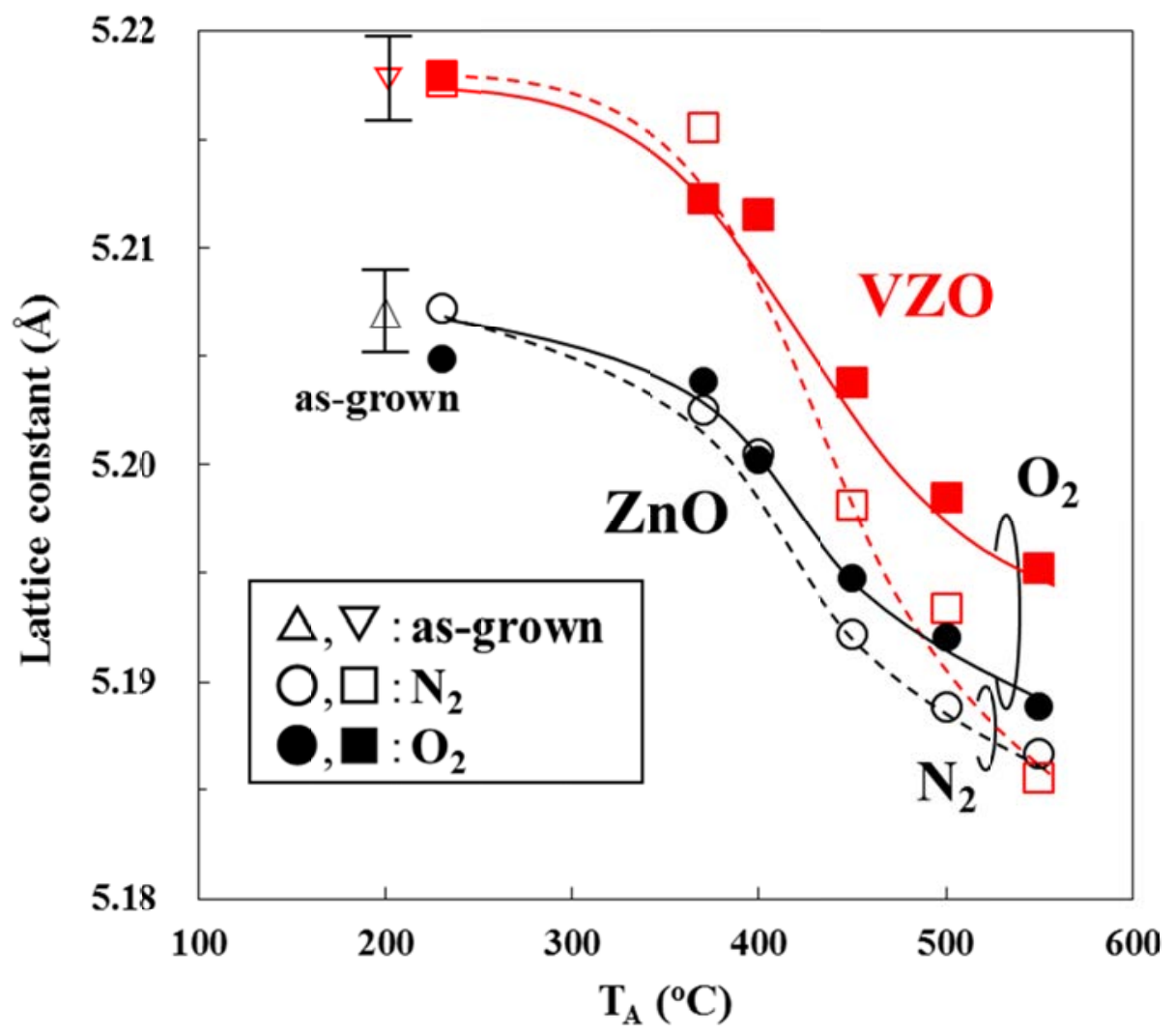


Fig. 6 H. Chiba et al.
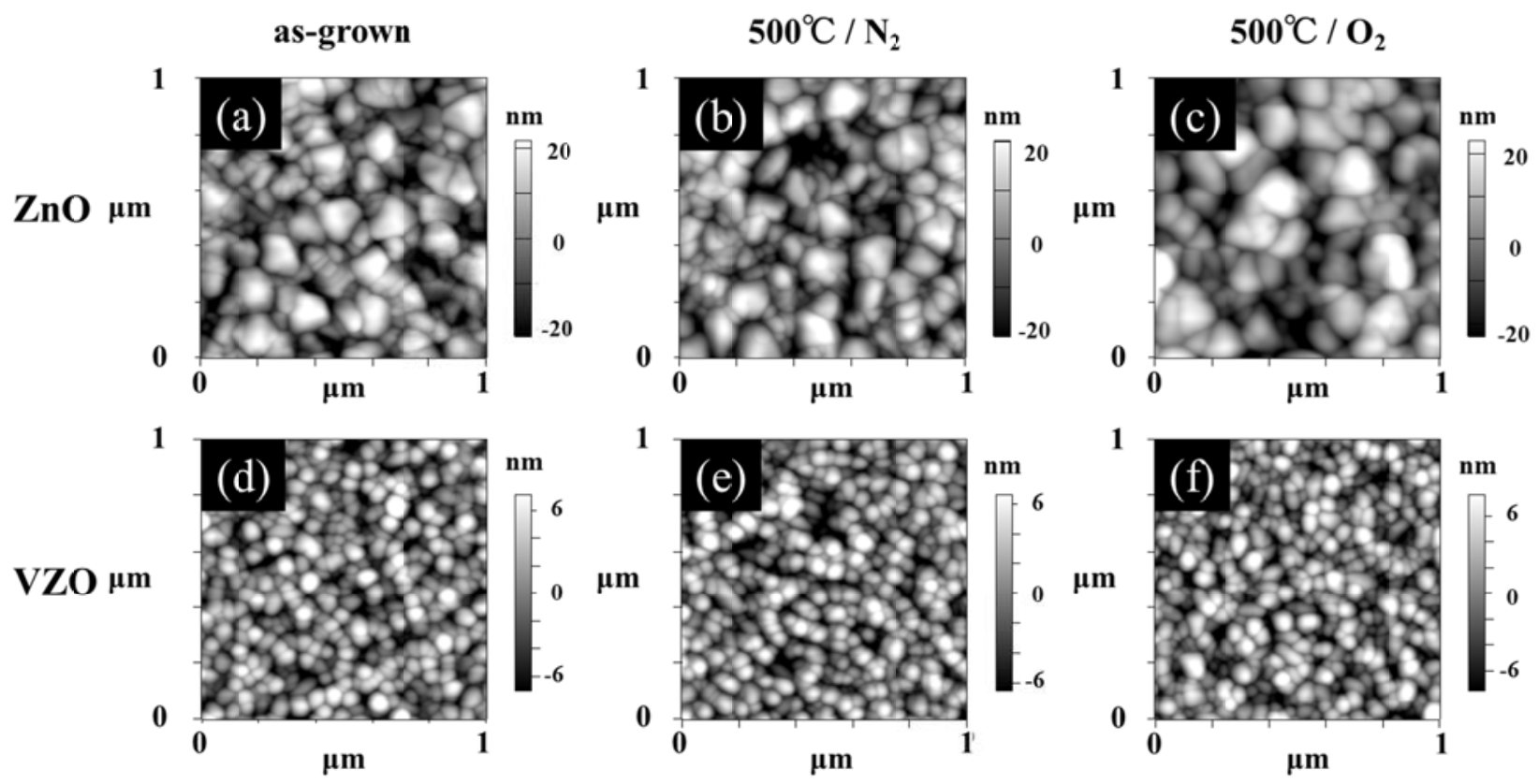